\title{
Distant Metastases from a Small Renal Cell Carcinoma in a Renal Allograft Recipient with Prostate Carcinoma: A Case Report
}

\section{Prostat Kanserli Bir Renal Allogreft Alıcısında Küçük Renal Hücreli Karsinomdan Uzak Metastazlar: Bir Olgu Sunumu}

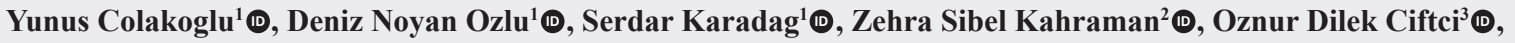 \\ Mehmet Dikec $^{4}$ (D, Suheyla Apaydin ${ }^{5}$ (D, Ali Ihsan Tasci ${ }^{1}$ (D)
}

\begin{abstract}
${ }^{1}$ Department of Urology, University of Health Sciences, Dr. Sadi Konuk Training and Research Hospital, Istanbul,Turkey ${ }^{2}$ Department of Pathology, University of Health Sciences, Dr. Sadi Konuk Training and Research Hospital, Istanbul,Turkey ${ }^{3}$ Department of Nuclear Medicine, University of Health Sciences, Dr. Sadi Konuk Training and Research Hospital,Istanbul,Turkey ${ }^{4}$ Department of Nephrology, University of Health Sciences, Dr. Sadi Konuk Training and Research Hospital, Istanbul,Turkey ${ }^{5}$ Department of Nephrology, Yeditepe University Faculty of Medicine, Istanbul, Turkey
\end{abstract}

Cite as: Colakoglu Y, Ozlu DN, Karadag S, Sibel Kahraman Z, Dilek Ciftci O, Dikec M, Apaydin S, Tasci AI. Distant metastases from a small renal cell carcinoma in a renal allograft recipient with prostate carcinoma: a case report. Grand J Urol 2022;2(1):38-41.

Submission date: 25 March $2021 \quad$ Acceptance date: 27 August $2021 \quad$ Online First: 27 September 2021

Publication date: 20 January 2022

Corresponding Author: Deniz Noyan Ozlu / University of Health Sciences, Dr. Sadi Konuk Training and Research Hospital, Istanbul, Turkey / noyanozlu@hotmail.com / ORCID ID: 0000-0003-2435-5482

\begin{abstract}
Immunosuppressive therapy is related to the increasing frequency of malignancies after transplantation. A small percentage (4.6\%) of malignancies seen in kidney transplant patients are renal cell carcinomas (RCC) which occur almost exclusively in native kidneys. The prognosis of RCC largely depends on the presence of metastasis. Metastatic disease is very rare in small renal masses. In this case report, we aimed to present our case of approximately $4 \mathrm{~cm}-\mathrm{mass}$ of metastatic RCC in our kidney transplant patient. During the examination due to exhaustion and weight loss, multiple suspicious metastatic lesions were observed in non-contrast computed tomography. In the patient who had multiple bone metastases on the whole-body bone scintigraphy, prostate cancer metastasis was considered in the first plan due to a history of prostate cancer before transplantation. This diagnosis could not be supported with prostatespecific membrane antigen-positron emission tomography/computed tomography (PSMA-PET/CT) scan. Whole body 18F-fluorodeoxyglucose positron emission tomography/computed tomography (18F-FDG PET/CT) was performed. A hypermetabolic mass lesion in the left kidney, multiple hypermetabolic lesions in the liver, in the left aortorenal junction, and in the skeletal system were observed. A biopsy was performed from the metastatic mass in the right lobe of the liver and the result was reported as renal cell carcinoma metastasis. Immunohistochemistry evaluation demonstrated positive staining for PAX-8, CK19, CD10 and negative staining for CK7, CK20, GATA-3, NAPSIN A, TTF-1, PSAP, glutamine synthetase and arginase. With all these findings, it was thought that the primary of metastases was the 4-cm mass in the left native kidney.
\end{abstract}

Keywords: kidney transplant, distant metastasis, small renal mass, renal cell carcinoma, immunosuppression

Öz

İmmünosüpresif tedavi, transplantasyon sonrası malignitelerin görülme sıklığının artmasıyla ilişkilidir. Böbrek nakilli hastalarda görülen malignitilerin \%4,6's1 renal hücreli karsinom (RHK)'dur ve neredeyse sadece nativ böbreklerde ortaya çıkar. RHK'un prognozu büyük ölçüde metastaz mevcudiyetine bağlıdır. Küçük böbrek kitlelerinde metastatik hastalık çok nadir görülmektedir. Biz bu olgu sunumunda, böbrek nakilli hastamızda nativ böbrekte ortaya çıkan yaklaşı 4 santimetrelik metastatik RHK vakamızı sunmayı amaçladık. Genel durum bozukluğu ve kilo kaybı olması nedenli tetkik edilirken çekilen kontratsız bilgisayarlı tomografide multipl, metastaz şüpheli lezyonlar izlendi. Tüm vücut kemik sintigrafisinde multipl kemik metastazları izlenen hastada, nakil öncesi prostat kanseri öyküsü olması nedenli ilk planda prostat kanseri metastazı düşünüldü. Çekilen PSMA-PET/CT'de bu tanı desteklenemedi. Bunun üzerine çekilen tüm vucut FDG-PET/CT'de sol böbrekte hipermetabolik kitle lezyonu, karaciğerde multiple hipermetabolik lezyonlar, sol aortarenal mesafede multiple hipermetabolik lenf nodları, iskelet sisteminde multiple hipermetabolik lezyonlar izlendi. Karaciğer sağ lobdaki metastatik kitleden biyopsi yapıldı ve patoloji sonucu renal hücreli karsinom metastazı olarak geldi. İmmünohistokimya değerlendirmesi PAX-8, CK19, CD10 için pozitif boyama ve CK7, CK20, GATA-3, NAPSIN A, TTF-1, PSAP, glutamin sentetaz ve arginaz için negatif boyama gösterdi. Tüm bu bulgular eşliğinde, metastazların primer odağının sol nativ böbrekteki 4 santimetrelik kitle olduğu düşünüldü.

Anahtar kelimeler: böbrek nakli, uzak metastaz, küçük renal kitle, renal hücreli karsinom, immünosupresyon

$\begin{array}{clll}\text { ORCID ID: Y. Colakoglu } & 0000-0001-6432-765 X & \text { O.D. Ciftci } & 0000-0002-7715-5276 \\ \text { S. Karadag } & 0000-0002-1420-4536 & \text { M. Dikec } & 0000-0003-1318-6556 \\ \text { Z.S. Kahraman } & 0000-0003-3902-8265 & \text { S. Apaydin } & 0000-0001-6224-405 X\end{array}$




\section{Introduction}

Kidney transplantation is one of the best treatment options for end-stage renal disease (ESRD) patients. As the survival of the graft after transplantation prolongs, life expectancy increases. However, patients face late-term complications as they live longer. Malignancies, which are among the most important of these complications, are the second most common cause of death in renal transplantation recipients after cardiovascular diseases [1].

\section{Case}

A 62-year-old male patient became a preemptive renal transplant candidate due to ESRD secondary to hypertensive nephropathy. He was also suffering from lower urinary system symptoms and his prostate-specific antigen (PSA) level was 2.36 $\mathrm{ng} / \mathrm{mL}$ (range: $0-4 \mathrm{ng} / \mathrm{ml}$ ) during the transplant preparations. Upon monitoring bilateral contour irregularity in the prostate on digital rectal examination, the patient underwent transrectal ultrasound-guided prostate biopsy and the result was prostatic adenocarcinoma with Gleason pattern $6(3+3)$ at $1 / 10$ foci. A total of 6720 cGy primary radiotherapy was applied on the patient's prostate in 28 fractions at daily doses of $240 \mathrm{cGy}$ per fraction dose with volumetric modulated arc therapy (VMAT) technique using a linear accelerator device. PSA value was $0.24 \mathrm{ng} / \mathrm{mL}$ in the fifth month following radiotherapy.

The patient underwent a robot-assisted living donor kidney transplantion using the kidney donated by his wife. As immunosuppressive treatment, he was given methylprednisolone in the induction period and the maintenance was provided with mycophenolic acid, tacrolimus, and prednisolone.

The patient was followed up with routine annual ultrasonography (US). Two years after surgery, based on the noncontrast computed tomography taken while examining the patient for exhaustion and weight loss, lesions were detected in the left kidney. The largest having dimensions of $38 \times 27 \mathrm{~mm}$ which were evaluated as complicated hemorrhagic cysts. There was a lymph node in the left aortorenal junction and hyperdense lesions were noticed on the right iliac bone, right femoral neck, and left pubic bone. There was no evidence of malignancy in the endoscopy and colonoscopy of the patient who also had microcytic iron deficiency anemia. Multiple suspicious metastatic lesions were detected in the liver in the contrast-enhanced magnetic resonance imaging (MR) of the patient, the biggest of them was in segment 8 and had a diameter of $12 \mathrm{~mm}$. Multiple simple and complicated hemorrhagic cortical cysts were noticed in both kidneys. There were multiple lymph nodes around the left renal vein, the biggest of them had the dimensions of $25 \times 16 \mathrm{~mm}$ and a mass suggesting renal malignancy in the first place with a size of $39.5 \times 24.5 \mathrm{~mm}$ in the upper-middle zone of the left kidney were observed (Figure 1). Multiple metastatic nodules were noticed in all bones in the sections covered in the abdomen MR imaging area.

Whole-body bone scintigraphy of the patient was compatible with multiple bone metastases and prostate cancer metastasis were first considered since the patient had prostate cancer diagnosis before transplantation. The latest PSA level of the patient was $0.28 \mathrm{ng} / \mathrm{mL}$ and heterogeneous foci of low-level gallium-68

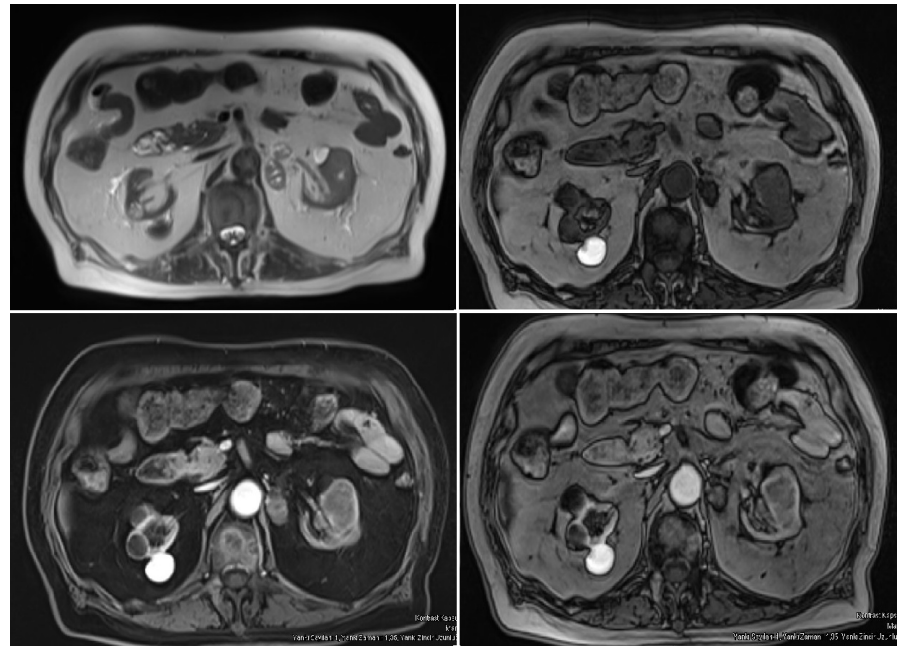

Figure 1. Contrast-enhanced magnetic resonance imaging showing a mass with a size of $39.5 \times 24.5 \mathrm{~mm}$ in the upper-middle zone lateral of the left kidney

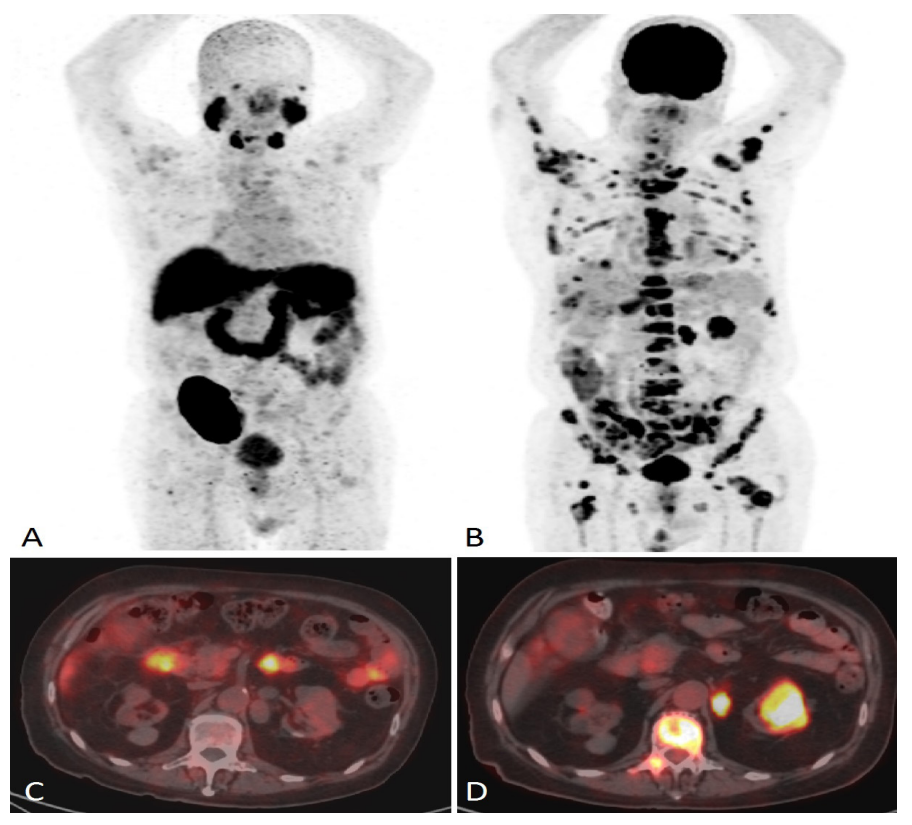

Figure 2A- Coronal image of PSMA-PET/CT: Heterogeneous mild Ga-68 PSMA uptake in the skeletal system and slightly increased heterogeneous Ga-68 PSMA uptake in the prostate gland, B- Coronal image of 18F-FDG PET/CT: A hypermetabolic mass lesion in the left kidney, multiple hypermetabolic lesions in the liver and multiple hypermetabolic lesions in the skeletal system, C- Axial image of PSMA-PET/CT: No pathological Ga-68 PSMA involvement was detected in the $40 \times 32 \mathrm{~mm}$ lesion in the left kidney, D- Axial image of 18F-FDG PET/CT: Increased FDG uptake is observed in the 40x32 mm lesion in the left kidney (Suv Max: 18.82)

uptake were observed in the skeletal system in prostate-specific membrane antigen-positron emission tomography/computed tomography (PSMA-PET/CT) and Ga-68 PSMA uptake was not observed in other metastatic lesions. Ga-68 PSMA uptake was detected in the lesion in the left kidney. Since diagnosis of prostate cancer metastasis was not quite possiblly made based on these findings, whole body $18 \mathrm{~F}$-fluorodeoxyglucose positron emission tomography/computed tomography (18F-FDG PET/ CT) was performed. A hypermetabolic mass lesion in the left 


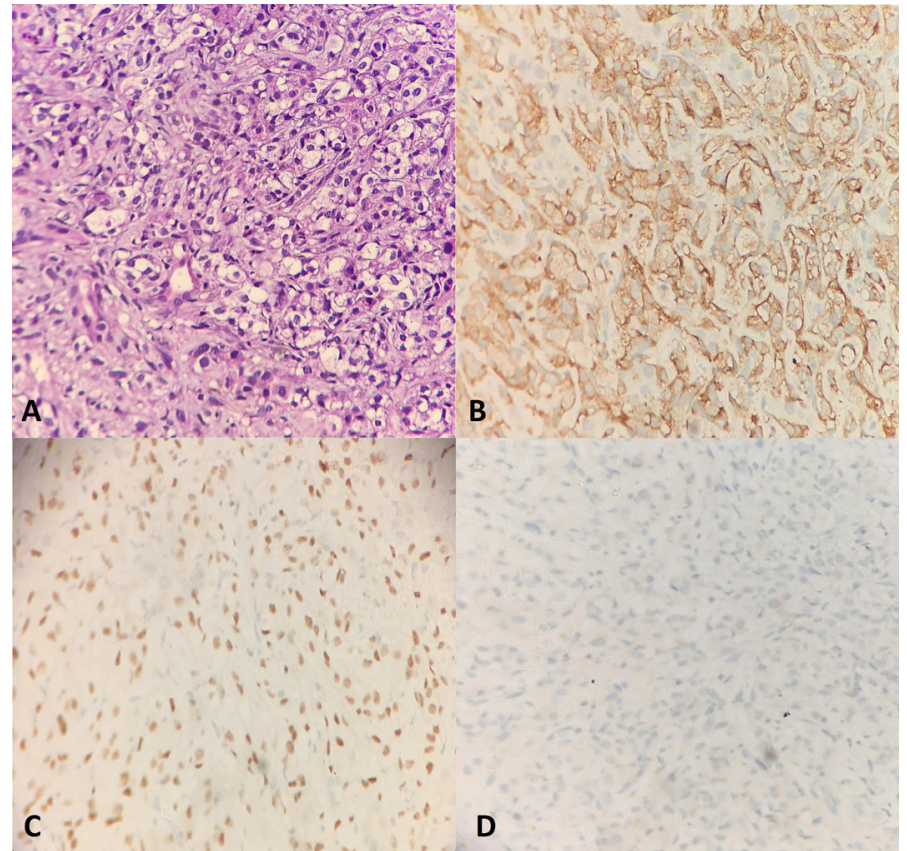

Figure 3. Core needle biopsy from the metastatic mass in the right lobe of the liver; diffuse tumoral infiltration that makes nesting locally, with large hyperchromatic nucleus and clear cytoplasm A- Hematoxylin \& Eosin x400, B- Positive staining for CD10, C- Positive staining for PAX-8, D- Negative staining for PSAP

kidney, multiple parenchymal and subpleural millimetric nodules in both lung parenchymas, multiple hypermetabolic lesions in the liver, and the skeletal system multiple hypermetabolic lymph nodes in the left aortorenal junction, and increased uptake of contrast material in the area of mural induration in the distal part of the duodenum were observed (Figure 2).

A core needle biopsy was performed from the metastatic mass in the right lobe of the liver, and the result was renal cell carcinoma (RCC) metastasis (Figure 3). Immunohistochemistry evaluation demonstrated positive staining for PAX-8, CK19, CD10 and negative staining for CK7, CK20, GATA-3, NAPSIN A, TTF-1, PSAP, glutamine synthetase and arginase. All these findings suggested that the primary focus of these metastases was the 4-cm mass in the left native kidney. The patient was started on sunitinib therapy and palliative radiotherapy was planned for bone metastases.

\section{Discussion}

At the present time, renal transplantation has become one of the primary treatment options in ESRD patients because of its superiority to dialysis in terms of cost-efficiency and quality of life [2]. Malignancies constitute one of the most important complications limiting survival in these patients, and $4.6 \%$ of malignancies seen in kidney transplant patients are metastases from RCC [3]. Renal malignancies are the third most common cause of death associated with malignancy at a rate of 9.8\% [4].

The mechanism of RCC development in kidney transplant patients is still not fully elucidated. As is known, the best-defined risk factors for RCC are smoking, hypertension, obesity and family history [5]. In addition to the well-known general risk factors, in transplant kidney recipients; the type of immunosuppression, primary disease of the native kidney, recipient/donor age, duration of dialysis before transplantation, and presence of microscopic hematuria are other risk factors for the development of RCC [6].

To maintain long-term allograft function, use of potent immunosuppressive agents is imperative to prevent acute and chronic allograft rejection. Immunosuppressive treatment is related to the increase in the prevalence of malignancies after transplantation [3]. It is also well known that RCC is an immunogenic phenotype that is sensitive to immunotherapy by inducing a potential immune response. It has been shown that RCC cells could escape from the immune cells such as T-cells by down-regulating HLA molecules in immunosuppressed recipients [7].

As in our patient, RCC occurs almost only in native kidneys in transplant recipients [3]. The risk of RCC in native kidneys in the acquired cystic disease of the kidney and end-stage renal failure is $3-7 \%$, which is nearly 100 times its incidence in the general population [8]. In the recent study performed by Eggers et al., prevalence of RCC was found to be $1.2 \%$ in native kidneys and $0.4 \%$ in allografts [9]. In the study of Moris et al., the average time until the diagnosis of RCC in native kidneys after transplant was 151 months. Most of these patients were diagnosed incidentally. Compared to other malignancies (stomach, lung, colorectal, prostate, and breast cancers), RCC was observed at a later stage of the disease in these patients. However, its prognosis was better compared to other malignancies, except for breast cancer [10].

The prognosis of RCC largely depends on the presence or absence of metastatic disease. The most appropriate treatment for the non-metastatic disease is surgery, and the associated survival is prolonged, while 5-year survival rate in metastatic disease decreases to $10 \%$ [11]. The incidence of metastatic disease is directly proportional to the size of the primary mass. Metastasis is less likely in masses smaller than $5 \mathrm{~cm}$ in diameter [12].

Most RCCs detected in transplant recipients are asymptomatic, usually incidentally diagnosed, and have a good prognosis because they are mostly low grade and stage. However, the prognosis of metastatic RCC is poor [10]. Metastatic disease is quite rare in small renal masses and thus active surveillance can also be an option for these lesions. The primary mass of our patient can also be defined as a small renal mass since it was only $4 \mathrm{~cm}$ in diameter. In the retrospective study conducted by Thompson et al., among 781 patients with a tumor mass less than $3 \mathrm{~cm}$ in diameter, only one patient had metastatic disease at diagnosis [13].

RCC, which makes up about $2 \%$ of all cancers, has been seen more frequently in the last 50 years with the development of imaging techniques [12]. Most transplant units do not take a specific approach to screening for RCC in native kidneys or renal allografts of renal transplant recipients due to its low incidence. Studies for modeling the performance of US scanning has shown that its cost-effectiveness is low. According to Wong et al., with routine annual US screening for RCC, survival can increase by $25 \%$. However, there is no evidence of its cost-effectiveness, even for kidney recipients at high risk for disease [14].

Studies contrary to this view are also present. Klein et al. recommended US once in every two years for the early detection of RCC [5]. Eggers et al. supported this approach and even 
recommended annual screening for patients getting ready for a kidney transplant and ESRD patients receiving dialysis treatment [9]. Moris et al. also defended the necessity of routine ultrasound scanning for renal transplant patients during the first five years after transplantation for early stage detection of a malignancy [10]. In our institute, we also perform screening with US annually after renal transplantation.

In kidney transplant patients, immunosuppressive agents constitute a risk factor for the development of malignancy. Renal malignancies are an important cause of morbidity and mortality in these patients. Survival in RCC is significantly associated with the presence of metastases, which can be rarely seen in small renal masses. In this respect, the early diagnosis of RCC provides an advantage in terms of survival. Because of the risk of RCC, regular US scanning of the native kidneys of kidney recipients should be considered.

\section{Ethics Committee Approval: N / A.}

Informed Consent: An informed consent was obtained from the patient.

Publication: The results of the study were not published in full or in part in form of abstracts.

Peer-review: Externally and internally peer-reviewed.

Authorship Contributions: Any contribution was not made by any individual not listed as an author. Concept - Y.C., D.N.O.; Design - S.K., Z.S.K.; Supervision - Y.C., D.N.O.; Resources - S.K., Z.S.K.; Materials - Y.C., S.K.; Data Collection and/or Processing - Z.S.K., D.N.O.; Analysis and/or Interpretation Y.C., S.A.; Literature Search - Y.C., S.A.; Writing - Y.C., D.N.O.; Critical Review - Y.C.

Conflict of Interest: The authors declare that they have no conflict of interest.

Financial Disclosure: The authors declare that this study received no financial support.

\section{References}

[1] Végsö G, Toronyi E, Hajdu M, Piros L, Görög D, Deák PA, et al. Renal Cell Carcinoma of the Native Kidney: A Frequent Tumor After Kidney Transplantation with Favorable Prognosis in Case of Early Diagnosis. Transplant Proc 2011;43:1261-3. https://doi.org/10.1016/j.transproceed.2011.03.068.

[2] Moris D, Lu L, Qian S. Mechanisms of Liver-induced Tolerance. Curr Opin Organ Transplant 2017;22:71-8. https://doi.org/10.1097/MOT.0000000000000380.

[3] Penn I. Primary Kidney Tumours Before and After Renal Transplantation. Transplantation 1995;59:480-5. https://pubmed.ncbi.nlm.nih.gov/7878750/.

[4] Farrugia D, Mahboob S, Cheshire J, Begaj I, Khosla S, Ray D, et al. Malignancy-related Mortality Following Kidney Transplantation is Common. Kidney Int 2014;85:1395-403. https://doi.org/10.1038/ki.2013.458.
[5] Klein JA, Gonzalez SA, Fischbach BV, Yango AF, Rajagopal A, Rice KM, et al. Routine Ultrasonography Surveillance of Native Kidneys for Renal Cell Carcinoma in Kidney Transplant Candidates. Clin Transplant 2016;30:946-53. https://doi.org/10.1111/ctr.12769.

[6] Filocamo MT, Zanazzi M, Li Marzi V, Guidoni L, Villari D, Dattolo E, et al. Renal Cell Carcinoma of Native Kidney After Renal Transplantation: Clinical Relevance of Early Detection. Transplant Proc 2009;41:4197-201. https://doi.org/10.1016/j.transproceed.2009.08.082.

[7] Tomita Y, Nishiyama T, Fujiwara M, Sato S. Immunohistochemical Detection of Major Histocompatibility Complex Antigens and Quantitative Analysis of Tumour-infiltrating Mononuclear Cells in Renal Cell Cancer. Br J Cancer 1990;62:354-9. https://doi.org/10.1038/bjc.1990.296.

[8] Tickoo SK, dePeralta-Venturina MN, Harik LR, Worcester HD, Salama ME, Young AN, et al. Spectrum of Epithelial Neoplasms in End-stage Renal Disease: An Experience from 66 Tumor-bearing Kidneys with Emphasis on Histologic Patterns Distinct from Those in Sporadic Adult Renal Neoplasia. Am J Surg Pathol 2006;30:141-53. https://doi.org/10.1097/01.pas.0000185382.80844.b1.

[9] Eggers H, Güler F, Ehlers U, Ivanyi P, Peters I, Grünwald V. Renal Cell Carcinoma in Kidney Transplant Recipients: Descriptive Analysis and Overview of a Major German Transplant Center. Future Oncol 2019;15:3739-50. https://doi.org/10.2217/fon-2019-0397.

[10] Moris D, Kakavia K, Argyrou C, Garmpis N, Bokos J, Vernadakis S, et al. De Novo Renal Cell Carcinoma of Native Kidneys in Renal Transplant Recipients: A Singlecenter Experience. Anticancer Res 2017;37:773-9. https://doi.org/10.21873/anticanres.11376.

[11] Tosoian JJ, Cameron JL, Allaf ME, Hruban RH, Nahime CB, Pawlik TM, et al. Resection of Isolated Renal Cell Carcinoma Metastases of the Pancreas: Outcomes from the Johns Hopkins Hospital. J Gastrointest Surg 2014;18:542-8. https://doi.org/10.1007/s11605-013-2278-2.

[12] Mai KT, Landry DC, Robertson SJ, Commons AS, Burns BF, Thijssen A, et al. A Comparative Study of Metastatic Renal Cell Carcinoma with Correlation to Subtype and Primary Tumor. Pathol Res Pract 2001;197:671-5. https://doi.org/10.1078/0344-0338-00144.

[13] Thompson RH, Hill JR, Babayev Y, Cronin A, Kaag M, Kundu S, et al. Metastatic Renal Cell Carcinoma Risk According to Tumor Size. J Urol 2009;182:41-5. https://doi.org/10.1016/j.juro.2009.02.128.

[14] Wong G, Howard K, Webster AC, Chapman JR, Craig JC. Screening for Renal Cancer in Recipients of Kidney Transplants. Nephrol Dial Transplant 2011;26:1729-39. https://doi.org/10.1093/ndt/gfq627. 